\title{
JaPANeSe Onomatopoeic Expressions With Quantitative MeANing
}

\author{
Nataliia Vitalievna KUTAFEVA \\ Novosibirsk State University, Russian Federation \\ natasha7362@mail.ru
}

\begin{abstract}
Grammatical category of quantity is absent in the Japanese language but there are many different grammatical, lexical, derivational and morphological modes of expression of quantity. This paper provides an analysis of the lexical mode of expression of quantitative meanings and their semantics with the help of onomatopoeic (giongo) and mimetic (gitaigo) words in the Japanese language. Based on the analysis, we have distinguished the following semantic groups: mimetic words A) existence of some (large or small) quantity (things, phenomena and people), B) degree of change of quantity; and onomatopoeic words A) single sound, B) repetitive sounds.
\end{abstract}

Keywords: category of quantity; Japanese language; onomatopoeic words; mimetic words.

\section{Povzetek}

Slovnična kategorija kvantitete je $v$ japonščini odsotna, vseeno pa je veliko načinov izražanja kvantitete, od slovničnih, leksikalnih, derivacijskih do morfoloških in drugih. Raziskava ponuja izsledke o leksikalnem načinu izražanja kvantitativnih pomenov in njihove semantike skozi onomatopejske in mimetične izraze $v$ japonščini. Na osnovi analize avtor loci več semantičnih skupin: mimetično besedje, ki ga nadalje razdeli na izraze za obstoj manjših ali večjih kvantitet in izraze za stopnje sprememb kvantitete, ter onomatopejsko besedje, ki vsebuje enkratne in ponavljajoče se glasove.

Ključne besede: kategorija kvantitete; japonščina; onomatopejske besede; mimetične besede

\section{Introduction}

This paper provides an analysis of onomatopoeic and mimetic words with quantitative meanings in the Japanese language. Section 2 discusses the structure of the category of quantity and meanings of quantity expressed with different parts of speech in the Japanese language. Section 3 focuses on the history of studying onomatopoeic and mimetic words in European philosophy, Japanese linguistics in Russia and Japanese linguistics in Japan, and defines major terms used for this phenomenon. Section 4 describes semantics of onomatopoeic and mimetic words with quantitative meanings, and Section 5 contains the conclusions of the study. 


\section{Meanings of quantity}

We study the category of quantity and modes of its expression in the Japanese language. The substance of the linguistic category of quantity is quantitative relations reflected by human mentality and linguistic forms.

The category of quantity represents a unity of two components, namely the number, meaning a discrete quantity, and the value, meaning a continuous quantity. The number and the value, as two constituents of the category of quantity, can be expressed variously in a language. Their usage spans all main levels of language structure - lexical, derivational, morphological, and syntactical. Regardless of their heterogeneous usage, they do not form a uniform system within grammar. One of the manifestations of the grammatical category of quantity is the category of number, which is absent in the Japanese language, except for the cases of personal and demonstrative pronouns.

We understand the category of quantity as a semantic category and, simultaneously, as a group of different methods, expressing this category, as well as according to further defined structure of semantic field. The nucleus is formed with quantitative numerals and pronouns having the category of number; the center is formed with of different parts of speech, namely the noun, the adjective and the adverb etc., and also combinations of words that express quantity. The middle part is formed with words including morphemes with quantitative meaning and the periphery is formed with phraseology and terminology. The category of quantity includes some functional and semantic categories, namely the singular, the plural and the numeral. The plural includes collective and representative meanings. The numeral includes precise, approximate, and indefinite meanings (Kutafeva 2014, p. 173).

We have studied the lexical mode of expression of quantity and clarified that quantitative nouns express meanings of the singular, the dual, the cumulative and the numeral. Quantitative adjectives express various grade of quantity. Complex verbs implicitly express quantity with various semantic nuances, namely reciprocal, plurality of subjects, plurality of recipients involved in verbal action, plurality of inanimate things, excessive quantity of people and things, repetitive verbal action, and simultaneous coexisting of plurality of people and things. Quantitative adverbs express quantitative manifestation of verbal and adjective signs with meaning of grade, value, change and approximations.

The aim of this study is to analyze the lexical mode of expression and meanings of quantity with the help of mimetic and onomatopoeic words.

\section{Brief story of study of onomatopoetic and mimetic words}

The study of sound symbolism has a long story, beginning from ancient Indian Vedas that were the first to mention linkages between sounds and meanings. This issue attracted attention of a number of philosophers such as Saint Augustine, Thomas 
Aquinas, Jean-Jacques Rousseau, and Rene Descartes. Philosophers of ancient Greece tried to define relations between characteristics of extra linguistic reality and forms of its linguistic expression.

Further study of sound symbolism is to a great extent bound with theory of sound mimesis. For example, one of the theories of language origin is based on the postulate that language is a result of imitation of natural sounds (sound mimesis) and phenomena (sound symbolism) of surrounding world.

At the beginning of $20^{\text {th }}$ century Edward Sapir, Otto Jespersen, and Charles Bally laid the foundation of theoretical studies of sound mimesis in its direct relation with sound symbolism.

According to Russian linguist Voronin (1990: 4) sound symbolism is studied in the terms of phonosemantics. Phonosemantics is a new science, which object is sound mimetic (onomatopoeic) and sound symbolic system, studied in terms of time and space. Other terms, such as 'phonosemics', 'linguistic iconism' and etc. are frequently used as well.

In the paper, we use the term 'onomatopoeic expression' combining mimetic and onomatopoeic words. Onomatopoeic expressions have national and cultural specifics and are frequently used in the Japanese language.

In the history of Japanese linguistics in Russia many linguists, such as Konrad (1937), Polivanov (1968), Kolpakchi (1936) and Feldman (1968) studied the Japanese onomatopoeic expressions. Modern grammars of Japanese written by Neverov (1977), Alpatov (2008) onomatopoeic expressions are studied as one of particular problems of the Japanese language. Various aspects of Japanese onomatopoeia are also studied by Russian linguists. For example, Cherevko (1971) studies structural, phonetic and semantic characteristics; Chironov (2004) studies phonosemantics; Rumak (2007) studies their translation into the Russian language; and Podshibyakina (2003) studies lexicological classification.

Japanese linguists actively study onomatopoeia. Kadooka (2007) tries to distinguish onomatopoeia as a separate lexical-grammatical class, having lexical, formal, prosodic and syntactic peculiarities.

Yamaguchi (2001 a) studies onomatopoeia in the diachronic aspect namely changes in the form and semantic depending on changes in surrounding reality.

Tamori and Schourup (1999) try to find linguistic universes, comparing Japanese onomatopoeia with that of Indo-European languages, for example Japanese and English.

One of the directions of studies is the terminological problem of onomatopoeia.

Chironov (2004) states that in addition to set expressions such as 'onomatopoeic words' (giongo and giseigo) and 'mimetic words' (gitaigo), other terms are used in Japanese linguistic works rather frequently. These words are 'copying word' (moshago) and 'transcription word' (tenshago) by Ishiguro Hiroaki, 'copy' (utsushi) by 
Ishigaki Sachio, and 'imitation word' (giyougo) and 'symbolic word' (shouchouji) by Kindaichi Haruhiko.

Tamori (2002) analyzes preceding theories and classifications, based on the type of denotatum, and uses terms 'onomatopoetic words' (giongo, giseigo), 'mimetic words' (gitaigo), 'motion mimetic' (gijougo), 'sensory words' (gijou kankaku) and 'emotion words' (gijou kannjō).

Yamaguchi (2001 b) studies onomatopoeia as expressive means in manga.

\section{Onomatopoeic and mimetic words with quantitative meanings}

We define Japanese onomatopoeic words (giongo and giseigo) as words directly imitating sounds of animate and inanimate nature, and mimetic word (gitaigo) as words describing physical and emotional states, actions and states of things. Onomatopoeic and mimetic words have lexical, structural and prosodic peculiarities; they are written with alphabet (kana) and used for emotional and laconic description and liveliness of speech.

About two thousands of onomatopoeic and mimetic words are frequently used in the Japanese language. Most of them are illogical and difficult to classify and to translate into foreign languages.

Grammatical function of onomatopoeic and mimetic words is adverb but they can be used as adjective, verb etc. As for onomatopoeic and mimetic words with quantitative meaning it may be noted that they are often used in sentence as adverbial phrase with or without particle to and as predicate with auxiliary verb suru.

To translate Japanese onomatopoeic expressions into English, we use the different modes in translation:

3. Reference to the Electronic resource 'Weblio Japanese English Dictionary' where part of Japanese onomatopoeia is absent though.

4. Retaining of quantitative meaning by direct translation with adverbs, adjectives, verbs and nouns.

5. Omission of onomatopoeic expressions in translation.

6. Usage of idioms.

At first, we describe the meaning of onomatopoeic expression, then give examples for using these onomatopoeic words and variants of translation.

We have found about 121 onomatopoeic expressions with quantitative meaning by sampling from 'Explanatory Japanese Russian dictionary of onomatopoetic lexica' Rumak (2012) and 'An illustrated dictionary of Japanese and onomatopoeic expressions' Gomi (2000).

Some of onomatopoeic expressions can function both as onomatopoeic and mimetic word and have two or more meanings. 
For example, zakuzaku describes the following meanings:

1. A large number of metal coins or jewels.

2. The sound of chopping vegetables.

3. The sound of gravel.

4. The sound of walking over the gravel or frost.

In the words such as mentioned above example we pay attention only to the quantitative meaning. In such cases onomatopoeic expression is used as rule as a mimetic word.

We have analyzed and distinguished the following semantic groups with the following meanings.

Mimetic words
A) Existence of some (large or small) quantity of people, things and phenomena.
B) Grade of change of quantity.

Onomatopoeic words
A) Single sound.
B) Repetitive sounds.

Then in each group, we have distinguished the subgroups emphasizing semantic nuances are emphasized from different points of view.

\subsection{Mimetic words}

\subsubsection{A large number:}

- un (to) (gitaigo, giongo) describes a very large number.

Unto kari ga aru.

I am in debt. I have a lot of debts.

- dossari (gitaigo) describes a large number, excess, abundance, stack, pile.

Anohito wa kane ga dossari aru.

He has plenty of money.

- gossori (gitaigo) describes a very large number simultaneously acquiring or losing things; many, completely; to the utmost, all.

Toranku no nakami wo gossori toreta.

All content of trunk (chest) was stolen.

- zakuzaku (gitaigo, giongo) describes a large number of metal coins or jewels.

Ōban koban ga zakuzaku detekita.

Old gold coins came out in plenty. 
Something gathered in a large number:

- Dosatto (gitaigo, giongo) describes something gathered in a large number in one place; jumble, crowd.

Kōkoku wo dasu to dōjini, mōshikomi ga dosatto kita.

As soon as I published advertisement, immediately a large number of applications appeared. I had barely managed to publish an announcement when a pile of applications appeared.

- kichikichi (gitaigo, giongo) describes jam-packed (with something, somebody).

Yogoreta yofuku de kichikichi no sūtsū kēsu.

A suitcase jammed with dirty clothes.

- gotagota (gitaigo) describes numerous things chaotically gathered in one place.

le no naka ga gotagota shiteiru.

The inside of house is in mess. The house is messy.

- wansa (gitaigo) describes a large of quantity, mass, crowd, oodles and used as a rule in speech about animate things.

Sono teido no hito nara wansa to iru.

There are lots of such people. There are pots of such people.

- zorozoro (gitaigo) describes a large number of people or things standing in line, crowd; continuous flow; one by one.

Zorozoro detekuru.

Come out in droves.

- ujauja (gitaigo) describes many small things gathered together and moving, swarm of insects or crowd of people.

Kodomo ga ujauja iru.

Have lots of children.

A large number connecting with variety:

- dekodeko (to) (gitaigo) describes crude things, accessories; heap of something, heap up something; fill something to the top.

Dekodekoto kazaru.

Decorate with a lot of things (trinkets). 
- kotekote (to) (gitaigo) describes a too large of quantity of piled up material (powder, make up), heavily, thickly; plaster.

Keshōhin wo kotekoteto nuru.

Makeup is thick. Too much makeup.

- betabeta (to) (gitaigo) describes the state when something is all plastered or covered with something, thickly strewn with something.

Kabe ni betabetato pira wo haru.

Plaster all walls with lots of piles. Plaster the entire wall with lots of posters.

- gotegote (to) (gitaigo) describes many gaudy decorations, excessively decorate something.

Mono wo gotegoteto egaku.

Paint something abundantly. Plaster something heavily.

Negative appreciation of excessive large quantity of something:

- dabudabu (to) (gitaigo, giongo) describes excess of something (water, money).

Ekitai ga dabudabu aru.

There is excess of (too much) liquid.

- gorogoro (gitaigo, giongo) describes the state when something is in excess, and as a result novelty and value are absent; loads of something; to be full of, to be strewn with.

Ano teido no bijin nara, Tōkyō ja gorogoro iru.

Well, there are lots of such beauties in Tokyo. Well, these beauties in Tokyo dime a dozen.

Quite a large number:

- tappuri (gitaigo) means generously, quite plenty, plentifully, abundantly.

Kare wa kane ga tappuri aru.

$\mathrm{He}$ is rolling in money. He has lots of money.

- tanmari (gitaigo) means considerable and sufficient quantity according to the person who gives estimation; sufficient degree.

Kane wo tanmari motte iru.

Be flush with money. 


\subsubsection{A small number.}

Expressing different grade of small number:

- chotto (chokkura (gitaigo) common speech) means a little, a bit of quantity.

Chokkura ore nimo waketekure yo.

Give me a little, too.

- choppori (gitaigo) means a very little bit, just a little, smidgen.

Sūryō ga choppiri da.

There is a very little something.

- pocchiri (gitaigo, giongo) means existing in a little bit, less than noting.

Kore, hon no pocchiri da kedo hatsumono da kara meshiagatte ne.

This is only a little, but it is the first harvest, please, taste some.

Various mode of existing in a small number:

- chobochobo (gitaigo) means a little, sparsely, drop-by-drop; head-to-head.

Koten wo hiraitemita ga mi ni kitekureta hito wa chobochobo datta.

Although I tried to open my exhibition, people who came to see were a few.

Although I tried to arrange my exhibition, few people came to see it.

- garagara (gitaigo, giongo) means a very few somebody, something in empty space; be nearly empty of.

Hōru wa mada mattaku garagara da.

There is practically nobody in hall yet. There is practically no one in the hall yet.

- chirahora, chirarihorari (gitaigo) means existing in a small number here and there, sparsely, a few.

Sakura ga chirahora sakihajimeta.

A few cherry blossoms are just begging to come out.

Using by small portions:

- chobichobi (gitaigo) means not at once but by small portions, a few.

Hige niwa shiroi mono ga chobichobi majitteita.

Gray hears are occasionally seen in her bears. Only a few grey hairs were sprinking in his beard.

- chibichibi (gitaigo) means doing something little by little, bit by bit to make it lasts as long as possible.

Hitori de chibichibi sake wo nomu.

Drink small sips of sake alone. 
Existing in single number:

- pocchiri (gitaigo) means existing in single number as a dot.

Gohan wo pocchiri kudasai.

Give me just a little rice.

- potsun (to) (gitaigo, giongo) means existing in single number as a bulge or hole.

Kare no herumetto tōjōbu ni ana ga hitotsu potsunto aiteita.

His helmet had a small hole at the top.

\section{Absence:}

- suttenten (gitaigo) means lost all (for example, money, shares, etc).

Kabu de suttentenni nacchatta.

I lost all money in the stock market. I diced away all money in the stock market.

- garan (to) (gitaigo, giongo) means empty, look empty.

le no naka wa garanto shite dare mo inakatta.

The house was deserted.

In conformity with certain quantity. These onomatopoeic expressions are used with numerals:

- kikkari, kakkiri (gitaigo) mean exactly, just, precisely.

Sētā to zubon de 1 man en kakkiri datta.

Sweater and pants were just 10,000 yen.

- chokkiri (gitaigo) means absence of excess, exactly.

le wo dete kaisha ni tsuku made chokkiri 2 jikan da.

It takes just 2 hours from home to working place.

\subsubsection{Change of quantity}

Sharp increase:

- pinto (to) (gitaigo, giongo) means the sharp increase in the value.

Ondo ga pinto agaru.

Temperature increases sharply. 
Sharp decrease:

- gakun (to) (gitaigo, giongo) means the sharp decrease in the value.

Sekiyu no kakaku wa gakunto sagatta.

The price of oil has dropped sharply.

- gakkuri (to) (gitaigo, giongo) means the acute decrease in the activity of a human or energy of a phenomena.

Nōryoku ga gakkurito ochiru.

Ability dramatically decreases.

- suton (to) (gitaigo, giongo) means something falls (price, support etc).

Jimintō no shijiritsu ga sutonto hetta.

The rating of Liberal Democratic Party has abated acutely. Support rate of Liberal

Democratic Party has acutely decreased.

Increase or decrease:

- dokat (to) (gitaigo) means increase or decrease in large quantity.

Seikatsuhi ga dokatto agatta.

The cost of living was zoomed (risen very rapidly).

- gasat (to) (gitaigo, giongo) means something quickly increase or decrease in large quantity at a time.

Tenkō fujun de yasai no nyūka ga gasatto ochita.

The stock of vegetables was quickly reduced because of bad (variable) weather.

\subsubsection{Energetic movement}

- dokadoka (to) (gitaigo) means energetic movement of a large number of people, things inside and outside, upstairs and downstairs.

Kodomo ga ōzei dokadokato basu ni norikondekita.

A lot of children rushed into our bus. A lot of children crowded into our bus.

- gappori (to) (gitaigo) means movement of money in large quantity at a time.

Keiba de gappori kasegu.

Make a pile of money on horseracing.

- gabat (to) (gitaigo) means movement of a large number of money, goods, etc.

Neagari wo mikonde gabatto kaikondeoita ga...

Expecting prices increase bought a large number of goods... 
- dosadosa (to) (gitaigo, giongo) means uninterrupted movement of a large number of things inside and outside.

Ōzei no hito ga hairiguchi kara dosadosato detekita.

A lot of people strode out of the entrance one group after another.

\subsection{Onomatopoeic words}

Single sound:

- garari (to) means a sound when you hit a solid single heavy object.

Gagarito doa wo akeru.

Open the door with a bang.

- potsunto means sound of drop falling.

Genkan no soto ni deru to amadare hitotsu potsunto kao ni atatta.

When I stepped out of the door, a rain drop fell on my face.

Repetitive sounds:

- gasagasa means a rustle.

Kare wa kaidan de gasagasa to iu oto wo kiita.

He heard the sound of rustling on the stairs.

- potsunpotsun means sounds of periodic drops fall one by one with small gaps.

Monohoshi zao kara potsunpotsun shizuku ga ochiru.

Raindrops fall one by one (periodically) from a drying rail.

- potsupotsu means consistent sounds of falling drops.

Ame ga potsupotsu furidashita.

Rain dots appears. Rain began to drip. Drops of rain began to drip.

Among the 121 extracted onomatopoeic expressions, 77 are mimetic words (some of them simultaneously are onomatopoeic words with the other meanings) and 53 are onomatopoeic words.

Among the extracted 77 mimetic words, the biggest group with meaning of 'a large number' is 40 words, then follow groups with the meanings 'change of quantity' is 15 , 'a small number' is 10 , 'in conformity with certain quantity' is 5 , 'existence in single number' is 4 and 'absence' is 3 .

Among the extracted 53 onomatopoeic words, groups expressing single and repetitive sounds are the same. 17 describe single sound and 17 describe repetitive sounds. Onomatopoeic words reproduce various modes of creation of sound. For 
example, a single sound hitting a hard object against a solid object, liquid sounds of blows on the subject, sounds of falling drops and so on.

\section{Conclusion}

Thus, we have analyzed onomatopoeic expressions with quantitative meaning in the Japanese language and distinguished the following semantic groups: large number with various nuances, a small number, existing in single number, absence, certain quantity, change of quantity and presentation of sounds. We distinguished subgroups within each larger group where the meaning of quantity or change of quantity is specified from different points of view. We can conclude that it is the semantics (quantity) that predetermines the quantitative composition of group, namely the number of mimetic words with semantic that they express is larger than the number of onomatopoeic words with semantics that they express. Onomatopoeic words express only two quantitative meanings: single and repetitive sounds.

\section{Sources}

Gomi T. (2000). 日本語擬態語辞典 [Nihongo gitaigo jiten]. Tokyo: The Japan Times Press.

Rumak, N. and Zolotova, O. (2012). Tolkovyi yaponsko-russkii slovar onomatopoeticheskih slov [Explanatory Japanese Russian dictionary of onomatopoeic words]. Moscow: Monogatari Press.

Weblio Japanese English dictionary http://ejie.weblio.jp/content

\section{References}

Alpatov, V. (2008). Yaponiya: yazyk i kultura [Japan: language and culture]. Moscow: Yazyki slavyanskih kultur Press. [Languages of Slavonic cultures Press].

Cherevko, K. (1971). Narechiya v sisteme chastei rechi sovremennogo yaponskogo yazyka [Adverbs in the system of parts of speech in the modern Japanese language] // Voprosy yaponskogo yazyka [Problems of Japanese language]. Moscow: Nauka Press, pages 79-112.

Chironov, S. (2004). Onomatopoeticheskie slova v sovremennom yaponskom yazyke. Problemy functsionorovaniya [Onomatopea in modern Japanese language. Problems of functions]. PhD thesis. Moscow.

Feldman, N. (1960). Yaponskii yazuk [Japanese language]. Moscow: Publishing House of Oriental literature Press. 
Kolpakchi, E. (1936). Stroi yaponskogo yazyka [Structure of the Japanese language]. Leningrad: Leningradskii nauchno-issledovatelskii institut yazykoznaniya Press [Leningrad research centre of linguistics].

Konrad N. (1937). Sintaksis yaponskogo nationalnogo litaraturnogo yazyka [Syntax of the national literary Japanese language]. Moscow: Izdatelstvo inostrannyh rabochih v SSSR [Publishing house of foreign workers in USSR].

Kutafeva N. (2014). Istoriografia categorii kolichestva v sovremennom yaponskom yazyke na osnove inostrannyh issledovanii. [Historiography of the category of quantity in the modern Japanese language based on foreign studies]. Vestnik of Novosibirsk State University. Series: History, Philology, 8:166-176.

Neverov, S. (1977). Osobennosti rechevoi i nerechevoi kommunikatsii yapontsev // Natsionalno-kulturnaya spetsifika rechevogo povedeniya [Peculiarities of verbal and nonverbal communication of the Japanese // National and cultural specific of verbal communication]. Moscow: Nauka Press.

Podshibyakina, A. (2003). Onomatopoeticheskaya leksika v yaponskon yazyke [Onomatopoeic wordstock in the Japanese language]. Moscow: Muravei Press.

Polivanov, E. (1968). Po povodu 'zvukovukh zhestov' yaponskogo yazyka [About 'sound gestures' in the Japanese language] // Statyi po obshemu yazykoznaniyu [Articles on general linguistics]. Moscow: Nauka Press.

Rumak, N. (2007). Teoreticheskie i practicheskie problem mezyazykovyh sootvetstvii (na primere perevoda onomatopoeticheskoi leksiki v yaponskom yazyke) [Theoretical and practical problems of correspondence between languages (exemplified by translation of Japanese onomatopoeia). PhD thesis. Moscow.

Kadooka, K. (2007). 日本語才ノマトペ語彙における形態的・音韻的体系性について [Nihongo onomatope goi ni okeru keitaiteki oninteki taikeisei ni tsuite [On the Morphologic and Phonological System in the Japanese Onomatopoeia Vocabulary ]. Tokyo: Kurosio shuppan.

Tamori, I. and Lawrence, S. (1999). オノマトペ・形態と意味 [Onomatope: keitai to imi]. Tokyo: Kuroshio shuppan.

Tamori, I. (2002). オノマトペ・擬音語・擬態語をたのしむ[Onomatope, giongo, gitaigo wo tanoshimu]. Tokyo: Iwanami shoten.

Voronin S. (1988). Osnovy fonosemantiki [Fundamentals of Phonosemantics]. Leningrad: Leningrad State University Press.

Yamaguchi, N. (2001a). 擬音語・擬態語の変化 [Giongo gitaigo no henka] 日本語史研 究の課題 [Nihongoshi kenkyū no kadai]. Musashino shoin, pages 240-262.

Yamaguchi, N. (2001 b). コミック世界の擬音語・擬態語 [Komikku sekai no giongo gitaigo] 日本語史研究の課題 [Nihongoshi kenkyuu no kadai]. Musashino shoin, pages 140-152. 
